DOI: $10.17805 /$ zpu.2015.3.17

\title{
Фольклор в сербской исторической литературе Средневековья *
}

\author{
С. В. АЛЕКСЕЕВ \\ (МОСКОВСКИЙ ГУМАНИТАРНЫЙ УНИВЕРСИТЕТ)
}

Статья посвящена отражению фольклорных сюжетов в сербской исторической литературе Средневековья.

Рассматриваются элементы фольклорного происхождения в ранних исторических памятниках, исторических житиях, в первую очередь в родословах и летописях позднего Средневековья. В этих памятниках отражаются уже те фольклорные сюжеты, которые зафиксированы и фольклористами Нового времени. Среди них - эпические сказания о Янке Сибинянине, о Косовской битве.

Специально рассматриваются следы эпических сказаний Косовского цикла в летописях и родословах XV-XVII вв. Двумя основными компонентами эпической истории сражения стали подвиг Милоша Кобилича, убившего турецкого султана Мурата, и измена Вука Бранковича, зятя погибшего на Косове сербского князя Лазаря. В статье показано, что мнение о позднем возникновении предания о Милоше как убийце Мурата подтверждается исследованием сербских исторических сочинений. В то же время Милош мог иметь одноименного исторического прототипа - серба, предположительно убившего султана Мусу после битвы на Марице 1413 г. Упоминание об этом лице в Младшей сербской летописи Первого вида, в своей основе восходящей к 1453 г., в Никольском списке XVI в. прямо заменяется упоминанием Милоша как убийцы Мурата.

Сказание об измене Вука Бранковича менее популярно в сербском летописании XVI-XVII вв., что можно связать с происхождением от Вука почитаемой династии Бранковичей. Но политические причины могли и ранее повлиять на замалчивание имен измен-

* Исследование проводится при поддержке РГНФ (проект «Памятники сербской средневековой историографии XII-XVII вв.: перевод и исследование», № 13-01-00118a).

The research is conducted with support from the Russian Foundation for the Humanities (the project "Monuments of the Serbian Medieval Historiography of the $12^{\text {th }}-17^{\text {th }}$ Centuries: Translation and Investigation", No. 13-01-00118a). 
ников Лазарю на Косове, которые остаются анонимными во всех ранних памятниках, тем не менее упоминающих об измене. В силу этого вопрос остается открытым, и фольклорные припоминания могут использоваться как один из источников его решения.

Ключевые слова: Средние века, южные славяне, Сербия, жития, летописи, родословы, фольклор.

\section{ВВЕАЕНИЕ}

Ч астоящая статья продолжает цикл работ автора, посвященных особенностям 1 сербской исторической литературы Средневековья. Как было показано ранее, многие характерные ее черты связаны с общим архаизмом сербского средневекового общества и культуры (Алексеев, 2014). В частности, огромное влияние на становление исторических жанров оказывала развитая в Сербии устная историческая традиция. Наиболее ярко ее воздействие проявилось в следовании сербских средневековых писателей схеме родового предания, «родослова» до прямого его переноса в литератуpy XIV в.

В данной статье рассматривается отражение фольклора в сербском историописании, в первую очередь - в родословах и летописях позднего Средневековья. В этих памятниках отражаются уже те фольклорные сюжеты, которые зафиксированы и фольклористами Нового времени. Такой анализ позволяет высказать некоторые новые соображения об исторической основе этих эпических эпизодов.

\section{ФОАЬКАОР В РАННИХ СЕРБСКИХ ИСТОРИЧЕСКИХ СОЧИНЕНИЯХ}

Устное предание и эпос, хранителями которого выступали в сербской традиции эпические певцы-гусляры, влияли на сербскую историческую литературу уже с ее зарождения. В древнейшем, видимо, ее памятнике - «Иетописи попа Ауклянина» (Алексеев, 2015) отражаются сверх канвы родословного предания королевской династии и целые эпические сказания. Это в основном сказания о предках-родоначальниках: первопредке дуклян Остроиле, предке жупанов Загорской Сербии (Рашки) Тихомире и его предшественнике Чаславе, предке правящей династии Аукли Белое. Замыкает ряд эпических героев создатель Ауклянской державы XI-XII вв. Стефан Воислав, которого «Аетопись» переименовывает в Аоброслава. Во всех случаях перед нами предстает воинский эпос, концентрирующийся на типичном сюжете «взятия» или «восстановления» страны.

При этом и в «Аетописи», и в позднейших памятниках информация устного происхождения об исторических или легендарных фактах вступала в сложное взаимодействие с шаблонами средневековой книжности. Такое взаимодействие, в котором часто факт подчинялся образности библейского или агиографического происхождения, неплохо изучено на русском материале (см.: Белова, Петрухин, 2008; Петрухин, 2013; Плотникова, 2013). Вместе с тем следует подчеркнуть, что литературный шаблон далеко не всегда замещал собой даже весьма отдаленную реальность. Темы и образы фольклора, влиявшие на книжников до самого их знакомства с книжностью, несомненно, были в сознании человека Средневековья гораздо прочнее. Тем более это касается общества со столь сильными пережитками архаики, как средневековое сербское.

В «историческую» сербскую агиографию, жития королей и первоиерархов фольклорные мотивы проникают довольно рано, в разные памятники с разной степенью ин- 
тенсивности. Следует иметь в виду, что большая часть наиболее крупных памятников сербской исторической агиографии носила отчасти «мемуарный», а иногда даже автобиографический характер. Однако по мере отдаления агиографов от описываемых ими событий в их произведениях усиливаются как «литературные», так и фольклорные черты.

Особенно характерно в этом отношении «Житие святого Савы», написанное в конце ХІІІв. Феодосием Хиландарцем (Живот ..., 1860). Это произведение уже в ХIX в. за неимением лучшего сравнения назвали «первым сербским романом». С тем же успехом можно было бы охарактеризовать его как «сербскую сагу». С одной стороны, Феодосий действительно черпал и идеи, и прямо отдельные отрывки из пространных византийских житий- «романов» метафрастовской традиции. С другой стороны, почти непрерывное в его тексте «действие», насыщенность диалогами, склонность описывать «приключения» совершенно определенно имеют и другой источник. Источник этот мощно повлиял и на языковое оформление текста. Феодосий - видимо, выходец из сербской знати - был знаком с устным творчеством, и недаром именно он первым из сербских писателей упоминает о придворных гуслярах. О том, насколько созданное Феодосием «Житие» отвечало запросам самых разных образованных слоев сербского общества, свидетельствует его уникальная популярность. Это самое распространенное по числу списков произведение сербской литературы Средневековья.

«Житие» Феодосия - наиболее насыщенный фольклорно-эпическими стилистическими элементами прозаический памятник Святосавского цикла. В нем сравнительно часто встречаются сербизмы, используются ритмическая речь, внутренние рифмы, чередование настоящего и прошедшего времени, повторы однокоренных или тех же слов. Подчас весьма вычурные синтаксические «плетения» внутри фраз напоминают приемы профессиональных эпических певцов в других средневековых культурах.

После падения сербской государственности под ударами турок-османов в XV в. героический эпос стал играть принципиально новую социальную роль, сохраняя в различных слоях народа память о древнем прошлом. Более того, «историческую» информацию черпают из него и иностранные авторы позднего Средневековья, пишущие о сербах. В то же время отражение эпоса в довольно скудном до начала XVIII в. сербском литературном творчестве ограничено. Аапидарная анналистическая форма сербских летописей этого периода не располагала к переложению фольклорных сюжетов. Однако примеры такого рода все же встречаются - как в виде «называния» эпических мотивов, так и в форме редких вставных рассказов. Такого рода рассказы встречаются в Савинской летописи конца XVII в. - ценном источнике о бытовании эпоса в этот период. Аетопись включает повествования о Янке Сибинянине - венгерском полководце Яноше Хуньяди, которого сербский эпос делает сыном сербского деспота Стефана Аазаревича (Стојановић, 1927b).

Но основной эпический цикл, отразившийся в сербском летописании XV-XVII вв., Косовский, ставший без преувеличения основой сербского «национального мифа». Ниже анализируются два основных компонента эпического представления о Косовской битве 1389 г., отразившиеся в позднесредневековом сербском летописании.

\section{Милош Кобилич}

А погиб наш воевода Милош У Ситницы, у реки студеной, Там немало перебил он турок: 
Милош поразил царя Мурата

И еще двенадцать тысяч турок.

Бог его родителей помилуй!

Будут сербы вспоминать юнака,

Будут сказывать о нем сказанья,

Сербы Милоша не позабудут,

Сербы Косова не позабудут

(пер. Н. Гальковского) (Песни ..., 1976: 224).

Так описывается кульминация и конец жизни одного из самых знаменитых эпических и национальных героев Сербии в песни «Царь Аазарь и царица Милица», записанной от гусляра XIX в. Т. Подруговича. Историчность Милоша Кобилича (Обилича) и убийства именно им на Косове турецкого султана Мурата вплоть до XIX в. практически не подвергались сомнению. Подвиг Милоша, которого эпос называет зятем князя Аазаря, несправедливо оскорбленным перед самой битвой и кровью доказавшим свою верность, стал неотъемлемой частью Косовской легенды.

Между тем уже первые шаги критического исследования сербской средневековой истории заставили усомниться не только в отождествлении Милоша с убийцей Мурата, но и в самой историчности этого лица. Ни в одном раннем (XIV-XV вв.) сербском

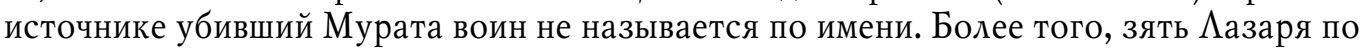
имени Милош не известен ни из актов, ни из ранних повествовательных источников. Впервые имя Милоша с отчеством или фамилией «Кобилич» появляется в турецких источниках и лишь в конце XV в. При этом отражается уже известная устная историческая традиция. Ее знает и автор сочинения «Записки янычара», написанного на рубеже XV-XVI вв. в польско-литовских землях сербом Константином Михайловичем из Островицы либо под его именем. Здесь сообщается, что на Косове «Милош Кобыла, рыцарь князя Аазаря, убил султана Мурада», а потом «один янычар принес голову Милоша Кобылича и бросил ее перед султаном» Баязитом, сыном Мурата (Записки ..., 1978: 52). Это, вероятно, старейшее надежное свидетельство бытования собственно сербского предания о Милоше. Зятем Аазаря он становится уже в устной и литературной традиции XVI в.

Правда, имя Милоша Кобилича фигурирует в указе (фирмане) султана Баязита, выпущенном будто бы после битвы на Косове и сообщающем о его вступлении на престол. Этот фирман выступал в качестве основного доказательства историчности Милоша и в российской науке, в том числе XX в. Однако подлинность документа, известного по сборнику XVIв., была подвергнута сомнению практически сразу после введения в научный оборот. Ааже если фирман в основе подлинен, то следует учитывать обстоятельства появления сборника, создававшегося для визиря Мехмет-паши Соколовича (1505-1579). Этот обращенный в ислам серб, не терявший связи с родным народом (и ставший, кстати, довольно ярким «антигероем» сербского эпоса), мог внести пояснения в старый текст, исходя из собственных знаний.

В сербских летописях имя Милоша (Кобилича, Обилича, Омилевича) в связи с Аазарем и Косовом фигурирует с XVI или даже лишь с XVII в. (см.: Стојановић, 1927а: 216-217, 288). Один из наиболее ранних сербских исторических памятников, сообщающий о его подвиге, - «Руварчевродослов» конца XVI в., созданный, возможно, сербом-эмигрантом в Московском царстве. Здесь говорится: «воевода Мазарев, Милош Кобилич, ножом проткнул Мурата на Косове» (там же: 54). В летописях XVIIв. Ми- 
лош также именуется «воеводой», «слугой Аазаревым» или просто «сербом». Браки дочерей Аазаря были известны из родословов. Потому только один летописец (Верковичев извод Младшей летописи, ок. 1638 г.) вслед за эпосом рискнул назвать Милоша княжеским зятем. Ему была «выдана» Елена Аазаревна (там же: 213), об иных двух браках которой хорошо известно из более ранних источников.

Итак, сербские летописи подтверждают сравнительно позднее сложение эпического сказания о Милоше как зяте князя Мазаря и убийце султана Мурата. Однако они же указывают возможный путь к решению вопроса об исторической основе этого образа. Спустя почти два с половиной десятка лет погиб другой турецкий султан - внук Мурата и сын Баязита Муса. Он был в 1413 г. разбит на реке Марице своим братом Мехмедом и вспомогательным войском от сербского деспота Стефана Аазаревича. Бежавший Муса, до этого не раз разоривший славянские области Балкан, был схвачен и убит - возможно, что сербами. Именно так рисует дело Сербская летопись старейшего, Первого вида (Младшие летописи Первой группы, по $\Lambda$. Стояновичу). Здесь утверждается, что Муса «заклан был Милошем» (там же: 224). Это известие, имевшееся в летописном своде примерно 1453 г., имеет несомненный приоритет перед всеми позднейшими. Итак, Милошем первоначально именовался в сербской исторической традиции убийца султана Мусы.

Имя Милоша под 6921 (1413) г. фигурирует во всех списках летописи Первого вида, кроме одного Никольского, датируемого XVI в. (возможно, первой половиной). И в этом же списке под 6897 (1389) г. появляется утверждение, что «Мурата убил Милош» (Новаковић, 1955: 166), - судя по всему, первое в сербской литературе. Таким образом, здесь мы имеем редчайший случай, когда по текстуальной истории письменного памятника можно проследить историю фольклорного сюжета. Сличение текстов сербской летописи наглядно показывает перенос имени Милоша из исторической реальности начала XV в. в эпическое пространство Косовского цикла.

Измена Вука Бранковича
А зачем о Вуке ты спросила?
На родителях его проклятье,
Будь он проклят и все его племя!
Изменил он на Косове князю
И увел с собой двенадать тысяч
Иютых латников с поля сраженья

(пер. Н. Гальковского) (Песни ..., 1976: 224).

Так отвечает в песне Т. Подруговича вестник с Косова княгине Милице на вопрос о другом ее зяте. В отличие от Милоша, Вук Бранкович - персонаж вполне исторический и действительно зять князя Аазаря. Он принадлежал к высшей сербской знати, считался потомком королевского рода Неманичей. Сын Вука и Мары Аазаревны, деспот Ажурадж (1427-1456) основал последнюю сербскую правящую династию, представители которой признавались главами сербов в венгерской эмиграции до начала XVI в.

История об измене Вука, закрепившаяся в фольклоре и приведшая, в частности, к разорению его гробницы в XIX в., вызвала сомнения в академической среде еще раньше, чем предание о подвиге Милоша. Турецкие и ранние западные источники о ней не упоминают. Вук после гибели Аазаря пытался сохранить самостоятельность от турок, 
первым из сербских владетелей вступил в сношения с венграми. В конце концов он лишился своих земель - султан передал их юному Ажураджу, а Вук умер в изгнании (1397). Именно служба Ажураджа туркам, особенно его борьба при поддержке турок против своего дяди Стефана Аазаревича в начале XV в., могли стать основой предания об измене его отца. Впрочем, сам Ажурадж, в период своего правления пытавшийся противостоять завоевателям, предстает в исторических преданиях скорее как трагическая фигура.

В сравнении со сказанием о Милоше измена Вука Бранковича - более редкий сюжет в сербском позднесредневековом летописании. Он присутствует в некоторых летописях XVII в. (см.: Стојановић, 1927а: 216-217). Иногда Вук называется «проклятым» или «неверным» при сообщениях о его смерти или о браке с дочерью Аазаря (там же: 212, 220). В одном случае (интерполированный Аечанский список относящегося в основе к XVI в. Янков-Аечанского извода) Вук обвиняется в том, что насильно выдал за султана Баязита дочь Аазаря (там же: 212-213). Это явный вымысел, поскольку в более ранних источниках ясно утверждается, что инициатива как минимум согласия на этот брак исходила от княгини-матери Милицы. В родословах об измене Вука не говорится вовсе. Очевидно, что летописцы, с одной стороны, учитывали общеизвестность предания об измене, с другой - избегали развивать эту тему. В последнем случае играло существенную роль представление о Вуке как родоначальнике почитаемой династии, «святой лозы» Сремских Бранковичей, давшей трех святых Сербской Церкви. Только в XVIII в. предание об измене Вука закрепляется в сербской письменной традиции. Впрочем, в далматинских исторических сочинениях ( «Королевство славян» М. Орбини и др.) этот эпический сюжет был воспринят еще в XVI в.

Однако как раз в данном случае, как ни парадоксально, вопреки сложившемуся научному консенсусу ставить вопрос об исторической основе предания больше оснований. Прежде всего следует отметить, что о самом факте измены или дезертирства части властелей на Косове упоминают уже самые ранние сербские источники. Так, Старшая сербская летопись редакции начала XV в. утверждает: «И в конце сражения того, - не ведаю, какие слухи об этом истинны, - то ли преданного кем-то из своей охраны, то ли, вернее, по сбывшемуся над ним (Аазарем) суду Божьему, захватил он (Баязит) сего в свои руки и после многих мук сам отсек честную и благоговейную главу его» (там же: 94). Здесь очевидно нежелание автора обсуждать тему измены, которое еще не может быть мотивировано каким-либо противоречием между народной и литературной традицией.

Оно может быть объяснено в первую очередь политическими причинами - нежеланием вносить раздор между влиятельными политическими фигурами Сербского княжества. Наиболее же влиятельным человеком в среде сербской аристократии, вторым лицом после фактической правительницы княгини Милицы, несомненно, являлся Вук. Все говорящие о нем источники рисуют его как фактически ее соправителя, в то же время существенно расширившего свою власть после гибели тестя. Каким бы то ни было способом, но силы свои на Косове Вуку удалось сохранить. Представляется, что именно эти факты, а не какие-то случайные обстоятельства позднейшей истории легли в основу народного мнения о княжеском зяте. И отражающие это мнение памятники фольклора, как думается, не следует полностью исключать из числа источников об обстоятельствах Косовской битвы. 
ЗАКАЮЧЕНИЕ

Как видно из этих примеров, фольклор, отражаясь в сербской исторической литературе Средневековья, в то же время не воспринимался ее создателями прямолинейно. Различные культурные и политические обстоятельства влияли на выбор сюжетов. При наличии альтернативных письменных источников восприятие эпических мотивов могло затормаживаться, и они ранее проявлялись в памятниках несербского происхождения. Тем не менее в конечном счете «фольклорная» точка зрения в памятниках традиционной словесности брала верх. Это особенно очевидно при обращении к пространным историческим сочинениям XVIIIв. - «Приче о бое косовском», «Троношскому родослову» и некоторым другим. В них рисуется «эпическая» картина сербской истории, в которой фольклорное уже однозначно превалирует над историческим. Однако этим памятникам предшествовала трехвековая эволюция традиционных исторических жанров, постепенное слияние «народной» устной и «элитарной»письменной исторической памяти.

\section{СПИСОК АИТЕРАТУРЫ}

Алексеев, С. В. (2014) Сербская историческая агиография: между хроникой и житием // Знание. Понимание. Умение. № 3. С. 148-156.

Алексеев, С. В. (2015) Метопись попа Ауклянина. СПб. : Петербургское востоковедение. 296 c.

Белова, О. В., Петрухин, В. Я. (2008) Фольклор и книжность: миф и исторические реалии. М. : Наука. 262 с.

Записки янычара (1978) / введение, пер. и коммент. А. И. Рогова. М. : Наука. 138 с.

Песни южных славян (1976) / вступ. статья, сост. и прим. Ю. Смирнова. М. : Художественная литература. $480 \mathrm{c.}$

Петрухин, В. Я. (2013) О фольклорных мотивах в ПВ $/ /$ Аревнейшие государства Восточной Европы. 2011 / отв. ред. Г. В. Глазырина. М. : ИВИ РАН. 594 с. С. 408-416.

Плотникова, О. А. (2013) Начало древнерусской словесности // Научные труды Московского гуманитарного университета. № 10. С. 4-20.

Живот светог Саве (1860) / изд. Ђ. Ааничић. Биоград. 220 с. (На серб. яз.)

Новаковић, Р. (1955) Никољски летопис // Зборник Филозофског факултета у Београду. Књ. 3. С. 160-169. (На сербск. яз.).

Стојановић, Љ. (1927а) Стари српски родослови и летописи. Београд; Сремски Карловци: Српска Краљевска академија. CVIII + 382 с. (На серб. яз.).

Стојановић, Њ. (1927b) Савински летопис // Прилози за књижевност, језик, историју и фолклор. Књ. 7. С. 169-178. (На серб. яз.).

Аата поступления: 30.05.2015 г.

\section{FOLKLORE IN SERBIAN HISTORICAL LITERATURE OF THE MIDDLE AGES \\ S. V. ALEKSEEV \\ (MOSCOW UNIVERSITY FOR THE HUMANITIES)}

The article is devoted to the reflection of folk stories in the Serbian historical literature of the Middle Ages.

We focus on the reflection of folklore in the early historical monuments, historical vitae, and, in the first place, in the genealogies and annals of the late Middle Ages. These monuments had reflected the folk stories which were recorded by folklorists of modern age. Among them are the epic tales of Janko Sibinyanin and of the Battle of Kosovo.

Our special attention was paid to the reflection of the epic tales of Kosovo cycle in the annals and genealogies of $15^{\text {th }}-17^{\text {th }}$ centuries. The two main components of the epic story of the battle were the 
feat of Milos Kobilic who killed Turkish sultan Murat, and the treason of Vuk Brankovic, the son-inlaw of Serbian Prince Lazar' who was killed in the battle. The article shows that the notion of the late occurrence of stories about Milos the assassin has indeed been confirmed by a study of Serbian historical works. At the same time, Milos might have had a homonymous historical prototype - the Serb who allegedly had killed Sultan Musa after the Battle of Maritsa in 1413. A mention of this person in the Serbian Junior chronicle of the First type, basically going back to 1453, was replaced in the 16th century Niko'lski copy with the name of Milos as the assassin of Murat.

The tale of Vuk Brankovic's treason was less popular in 16th and 17th century Serbian chronicles, which can be attributed to his status as the progenitor of the highly esteemed Brankovic dynasty. Political factors could have also affected the earlier silencing of the names of those who betrayed Lazar' in the Kosovo battle. In all early monuments they remain anonymous; the act of treason is, however, mentioned every time. The question thus remains open, and folklore mentions can be used in the search for potential solutions.

Keywords: Middle Ages, South Slavs, Serbia, vitae, annals, genealogies, folklore.

\section{REFERENCES}

Alekseev, S. V. (2014) Serbskaja istoricheskaja agiografia: mezhdu khronikoi i zhitiem [Serbian historical hagiography: between the chronicle and vita]. Znanie. Ponimanie. Umenie, no. 3, pp. 148-156. (In Russ.).

Alekseev, S. V. (2015) Letopis' popa Dukljanina [Chronicle of the Priest of Duklja]. Saint Petersburg, Peterburgskoe vostokovedenie. 296 p. (In Russ.).

Belova, O. V. and Petrukhin, V. J. (2008) Fol'klor i knizhnost': mif $i$ istoricheskie realii [Folklore and booklore: myth and realities]. Moscow, Nauka. 262 p. (In Russ.).

Zapiski janychara [Memoirs of a Janissary] (1978) / Intr., transl. and comm. A. I. Rogov. Moscow, Nauka. 138 p. (In Russ.).

Pesni juzhnyb slavjan [Songs of the South Slavs] (1976) / Intr., comp. and comm. Y. Smirnov. Moscow, Khudozhestvennaia literatura. 480 p. (In Russ.).

Petruhin, V. J. (2013) O fol'klornyh motivah v PVL [On the folklore motives in TBY]. In: Drevneishie gosudarstva Vostochnoi Evropy. 2011. Moscow, Institut of World History of Russian Academy of Sciences. 549 p. Pp. 408-416. (In Russ.).

Plotnikova, O. A. (2013) Nachalo drevnerusskoi slovesnosti [The origin of Old Russian literature]. Nauchnye trudy Moskovskogo gumanitarnogo universiteta, no. 10, pp. 4-20. (In Russ.).

Stojanovich, L. (1927b) Savinski letopis [Savinski annals]. Prilozi za knjizhevnost, jezik, istoriju i folklor, vol. 7, pp. 169-178. (In Russ.)

Stojanovich, L. (1927a) Stari srpski rodoslovi $i$ letopisi [Old Serbian genealogies and annals]. Beograd; Sremski Karlovci, Srpska Kraljevska akademija. CVIII + 382 p. (In Serb.).

Zhivot svetog Save [Vita of St. Sava] (1860) / ed. D. Danichich. Beograd. 220 p. (In Serb.)

Novakovich, R. (1955) Nikol'ski letopis [Nikol'ski annals]. Zbornik Filozofskog fakulteta u Beogradu, no. 3, pp. 160-169. (In Serb.).

Submission date: 30.05 .2015 .

Алексеев Сергей Викторович - доктор исторических наук, профессор, заведующий кафедрой истории Московского гуманитарного университета, председатель историко-просветительского общества «Радетель». Адрес: 111395, Россия, г. Москва, ул. Юности, д. 5, корп. 3. Тел.: +7 (499) 374-55-81. Эл. почта: ipo1972@mail.ru

Alekseev Sergey Viktorovich, Doctor of History, Professor and Chair, Department of history, Moscow University for the Humanities; Chair, "Radetel" Historical and Educational Society. Postal address: Bldg. 3, 5 Yunosti St., 111395 Moscow, Russian Federation. Tel.: +7 (499) 374-55-81. E-mail: ipo1972@mail.ru 